\title{
The Freedom of Expression in Global Perspective
}

\author{
Üner Daglier • Thomas E. Schneider
}

Published online: 16 October 2007

(C) Springer Science + Business Media, LLC 2007

Erratum to: Society

$$
\text { DOI 10.1007/s12115-007-9031-y }
$$

Correction: in article and in metadata, change author's last name Dağlier to Daglier-remove the accent mark from the last name.

The online version of the original article can be found at http://dx.doi. org/10.1007/s12115-007-9031-y.

Ü. Daglier

Cag University in Mersin,

Mersin, Turkey

T. E. Schneider $(\square)$

Editorial Institute, Boston University,

143 Bay State Road,

Boston, MA 02215, USA

e-mail: tschneid@bowdoin.edu 